\title{
Seasonal changes in bacterioplankton nutrient limitation and their effects on bacterial community composition in the NW Mediterranean Sea
}

\author{
Jarone Pinhassi ${ }^{1, *}$, Laura Gómez-Consarnau ${ }^{1}$, Laura Alonso-Sáez ${ }^{2}$, \\ Maria Montserrat Sala ${ }^{2}$, Montserrat Vidal ${ }^{3}$, Carlos Pedrós-Alió ${ }^{2}$, Josep M. Gasol ${ }^{2}$ \\ ${ }^{1}$ Marine Microbiology, Department of Biology and Environmental Sciences, University of Kalmar, Barlastgatan 11, \\ 39182 Kalmar, Sweden \\ ${ }^{2}$ Institut de Ciències del Mar-CMIMA (CSIC), Passeig Marítim de la Barceloneta 37-49, 08003 Barcelona, \\ Catalunya, Spain \\ ${ }^{3}$ Departament d'Ecologia, Universitat de Barcelona, Avda. Diagonal 645, 08028 Barcelona, Catalunya, Spain
}

\begin{abstract}
Bacterioplankton growth is expected to depend on the availability of organic and inorganic nutrients. Still, no studies have investigated how the magnitude and type of nutrient limitation experienced by marine bacteria change on a temporal scale. We carried out a series of nutrient enrichment experiments to examine the variability in nutrient limitation of bacteria in the NW Mediterranean Sea, at monthly intervals, over an 18 mo period. Short-term enrichment bioassays (24 $\mathrm{h}$ incubation) showed that bacterial P limitation could occur throughout the year, but was most pronounced during spring and summer, coinciding with very low concentrations of dissolved inorganic phosphorus and chlorophyll $a$, and higher N:P ratios. During the non-stratified period in autumn and winter, bacteria were at times strongly $\mathrm{C}$ limited. Inorganic nitrogen limitation was not detected at any time. Long-term bioassays with and without enrichment, where growth was monitored until stationary phase using the seawater dilution culture approach, largely confirmed the results from the short-term bioassays. Analysis of the bacterial assemblages in these cultures, using denaturing gradient gel electrophoresis (DGGE) and 16S rRNA gene sequencing, suggested that the growth of some central components of the native bacterioplankton assemblage (i.e. specific Roseobacter and Flavobacteria phylotypes) was restricted due to the limited availability of P in spring and summer. We conclude that seasonal variability in the type and severity of nutrient limitation can substantially contribute to the regulation of bacterioplankton growth and community composition, and thereby affect the turnover of dissolved organic matter and inorganic nutrients in the sea.
\end{abstract}

KEY WORDS: Marine bacteria $\cdot$ Nutrients $\cdot$ Bioassays $\cdot$ Seasonal variability $\cdot$ Diversity

\section{INTRODUCTION}

Marine microbes experience seasonally changing growth conditions that eventually lead to differences in the structuring of community composition over seasonal scales. Changes in inorganic nutrient availability are of decisive importance for defining ocean primary productivity and for regulating phytoplankton community composition and succession. The concentrations of dissolved inorganic nutrients in the photic zone of the sea are mainly regulated through physical mixing with deep water, e.g. autumn and winter overturn or upwelling, leading to increased concentrations and biological consumption by microorganisms that leads to their depletion. The variation in nutrient regimes affects phytoplankton production, diversity and succession (Smayda \& Reynolds 2001, 2003), but an understanding of how seasonal changes in nutrient 
availability affect bacterioplankton heterotrophic production and community composition is still lacking.

The primary limiting nutrient for bacterial growth differs between sea areas. It is generally assumed that growth of bacterioplankton in the Mediterranean Sea is limited by the availability of inorganic P (Zweifel et al. 1993, Thingstad et al. 1998, 2005, Zohary \& Robarts 1998, Sala et al. 2002, Tanaka et al. 2004, Pitta et al. 2005), while, for example, the availability of organic C or inorganic P or Fe can limit the growth of bacteria in the subarctic Pacific, the Sargasso Sea or Antarctica (Kirchman 1990, Pakulski et al. 1996, Cotner et al. 1997, Rivkin \& Anderson 1997). Considering the often large seasonal fluctuations in nutrient concentrations in the sea, variability in the type of bacterial nutrient limitation can be expected (Sala et al. 2002). Indeed, it has been speculated that inconsistent findings of $\mathrm{C}$ or $\mathrm{P}$ limitation in the Sargasso Sea may be explained by temporal variability (Cotner et al. 1997, Carlson et al. 2002, 2004). Studies in freshwater environments have shown substantial seasonal variability in bacterioplankton nutrient limitation in relation to nutrient availability, with bacterial growth responding primarily to $\mathrm{P}$ or combined $\mathrm{P}$ and $\mathrm{C}$ enrichments (Morris \& Lewis 1992, Carlsson \& Caron 2001). However, in the sea, little is known about the temporal variability in the kind and extent of nutrient limitation experienced by bacterioplankton and its consequences in terms of regulating bacterial growth.

Because heterotrophic bacteria are the major consumers of dissolved organic matter in the aquatic environment, limitation of bacterial growth by organic or inorganic nutrients can have important consequences in terms of biogeochemical C cycling. For example, modeling, experimental, and in situ results all show that labile DOC can accumulate when bacteria are limited by inorganic nutrients (Zweifel et al. 1995, Thingstad et al. 1997, 1999), which may occur for example in the P limited Baltic Sea in summer (Zweifel et al. 1995). In the Sargasso Sea, DOC also accumulates in summer (Carlson et al. 1994, 2002). In this sea, however, bacteria are limited by the availability of organic C in summer, and labile DOC is continuously taken up by bacteria while semilabile DOC resistant to rapid degradation by bacteria accumulates (Carlson et al. 2002, 2004). Thus, bacterial nutrient limitation may define whether DOC accumulated in surface waters is labile or not. This has important consequences in the long term for defining the quality of DOC that is exported to deep waters by convective processes (Murray et al. 1994) and in the short term for determining the ability of bacteria to take advantage of pulses of inorganic nutrients (Hagström et al. 2001).

Bacterioplankton community structure changes relatively fast in response to the growth and decay of different phytoplankton, indicating that dissolved organic matter from different algae select for different bacteria (Pinhassi et al. 2004, Abell \& Bowman 2005, Grossart et al. 2005). Further, experiments with estuarine bacterioplankton show that different complex dissolved organic carbon sources selectively stimulate the growth of specific phylotypes (Covert \& Moran 2001, Kisand \& Wikner 2003). In North Sea and east Mediterranean seawater dilution cultures, enrichment with easily degradable carbon sources (e.g. glucose) favored the growth of Vibrio species (Eilers et al. 2000, Pinhassi \& Berman 2003). Also, the growth of Gammaproteobacteria was preferentially stimulated by Fe enrichment in different seas where bacterial growth was limited by Fe availability (Hutchins et al. 2001). These studies focused mainly on the selective role of organic matter on the growth of specific bacteria, but also considered aspects of inorganic nutrient availability. Taken together, they suggest that changes in the availability of both organic and inorganic nutrients could be important for defining the composition of bacterial communities in the sea.

In the present study, we carried out a series of nutrient enrichment experiments to examine the extent of organic and/or inorganic nutrient limitation of marine bacterioplankton in a defined coastal marine area over an 18 mo period. To estimate nutrient limitation, we used 2 complementary bioassay approaches that are frequently used to investigate bacterial growth characteristics (see Pinhassi \& Berman 2003 for details of methodologies). Short-term enrichment bioassays ( $24 \mathrm{~h}$ incubation) were used to estimate the immediate growth response of the bacteria. Long-term bioassays, whereby growth was monitored until stationary phase using the seawater dilution culture approach, allowed us to evaluate how differences in nutrient availability affected particular members of the bacterioplankton assemblage. It was hypothesized that differences in the composition of the bacterial assemblage developing in seawater cultures with and without nutrient enrichment would depend on the type and extent of in situ nutrient limitation.

\section{MATERIALS AND METHODS}

In situ sampling. NW Mediterranean Sea water from $0.5 \mathrm{~m}$ depth was collected at monthly intervals between 28 January 2003 and 19 July 2004 (see Table 1), $1 \mathrm{~km}$ off the coast in the Bay of Blanes (The Blanes Bay Microbial Observatory, $41^{\circ} 40^{\prime} \mathrm{N}, 2^{\circ} 48^{\prime} \mathrm{E}$, $60 \mathrm{~km}$ north of Barcelona, Spain). Water was filtered through a $200 \mu \mathrm{m}$ mesh net, collected in a 25 l polycarbonate bottle (Nalgene), and brought to the laboratory for processing within $3 \mathrm{~h}$. For convenience, the sampling on 4 March 2003 is referred to as 'February 
2003', to avoid confusion with the sampling on 25 March 2003 (i.e. 'March 2003').

Chlorophyll a (chl a). Chl a was measured fluorometrically, from $200 \mathrm{ml}$ samples filtered onto GF/F filters (Whatman). The filters were ground in $90 \%$ acetone and left in the dark at room temperature for at least $2 \mathrm{~h}$. The fluorescence of the extract was measured with a Turner Designs fluorometer.

Chemical analyses. For analyses of dissolved nutrient concentrations, seawater samples were filtered through $0.2 \mu \mathrm{m}$ pore size, $47 \mathrm{~mm}$ diameter, polycarbonate filters (Supor-200; Gelman Sciences) using a polycarbonate filtration device (Millipore). All utensils in contact with the samples (filters, filter holder, tubes) were acid rinsed with $1 \mathrm{M} \mathrm{HCl}$ and extensively washed with MilliQ water prior to use.

Total dissolved nitrogen and phosphorus (TDN and TDP) were determined following the wet oxidation of additional filtered samples in alkaline and acidic persulfate, respectively, and the subsequent analysis of dissolved nitrate and phosphate (Grasshoff et al. 1983).

Dissolved inorganic nitrogen (DIN; $\mathrm{NO}_{3}{ }^{-}+\mathrm{NO}_{2}{ }^{-}+$ $\mathrm{NH}_{4}{ }^{+}$) and dissolved inorganic phosphorus (DIP; $\mathrm{PO}_{4}{ }^{3-}$ ) were measured spectrophotometrically with an Alliance Evolution II autoanalyzer following standard procedures (Grasshoff et al. 1983). Phosphate concentrations were also determined manually, using a $10 \mathrm{~cm}$ cuvette to increase the detection limit.

For dissolved organic carbon (DOC), $20 \mathrm{ml}$ samples were acidified with $16 \mathrm{mM} \mathrm{HCl}$ (final concentration) in polypropylene tubes, and stored at $4{ }^{\circ} \mathrm{C}$ until analysis. DOC was measured with a high temperature carbon analyzer (Shimadzu TOC 5000) at the intercalibration facilities at Umeå Marine Research Station (UMF), Sweden.

Short-term nutrient limitation bioassays. The effect of nutrient additions on the growth of heterotrophic bacteria was examined in short-term bioassays. Seawater was transferred to acid-rinsed $250 \mathrm{ml}$ polycarbonate bottles (Nalgene), and thoroughly rinsed with MilliQ-water and sample water. Nutrients were added to final concentrations of $24 \mu \mathrm{M} \mathrm{C}$ (glucose), $2 \mu \mathrm{M} \mathrm{N}$ $\left(\mathrm{NH}_{4} \mathrm{Cl}\right)$, and $0.6 \mu \mathrm{MP}\left(\mathrm{Na}_{2} \mathrm{HPO}_{4}\right)$, singly and in all different combinations in duplicate. Control bottles received no nutrients. After dark incubation for $24 \mathrm{~h}$ at in situ temperature, bacterial production and abundance were determined. In general, leucine incorporation rates in the unamended controls had increased 20 to $90 \%$ after $24 \mathrm{~h}$ incubation, compared to the rates measured upon sampling in situ (data not shown). Since the bacterial growth response determined by leucine incorporation was up to 10 times higher in the enriched treatments compared to the controls, while only minor changes $(<50 \%)$ were observed in bacterial abundance, we focused the subsequent analyses on the leucine incorporation data. Such delays in increase in bacterial abundance compared to leucine incorporation are most likely to be due to the longer time needed for biosynthesis before cell division compared to nutrient or tracer uptake.

Long-term nutrient limitation bioassays. For each seawater culture, approximately $1900 \mathrm{ml}$ of sampled water to be used as growth medium was filtered through a $0.2 \mu \mathrm{m}$ pore-size Sterivex filter capsule (Millipore) using a peristaltic pump. A total of $100 \mathrm{ml}$ inoculum was added to each culture to give a 20 -fold dilution of bacterial abundance. The inoculum was prepared by gravity filtration of sampled water through a $47 \mathrm{~mm}$ diameter $0.8 \mu \mathrm{m}$ pore size polycarbonate filter (Nuclepore). These filtration procedures resulted in cultures that were essentially free from heterotrophic flagellates grazing on bacteria, at least within the time frame of the experiments. The bioassays were done in 21 polycarbonate bottles (Nalgene). All utensils in contact with the samples were acid rinsed with $1 \mathrm{M} \mathrm{HCl}$ and extensively washed with MilliQ-water prior to use. Duplicate nutrient enriched cultures received a final concentration of $2.0 \mu \mathrm{M} \mathrm{N}$ $\left(\mathrm{NH}_{4} \mathrm{Cl}\right)$ and $0.6 \mu \mathrm{M} \mathrm{P}\left(\mathrm{Na}_{2} \mathrm{HPO}_{4}\right)$. Duplicate control cultures received no addition of nutrients. Seawater cultures were maintained at in situ temperatures in the dark for 68 to $85 \mathrm{~h}$ ( 45 to $55 \mathrm{~h}$ in the June to August 2003 experiments), after which samples for community DNA were collected. Near stationary phase bacterial abundance was reached after approximately $24 \mathrm{~h}$ (May to September 2003) or after 48 to $55 \mathrm{~h}$ in the remaining experiments

Bacterial abundance and production. Samples for enumeration of bacteria by flow cytometry were preserved with $1 \%$ paraformaldehyde and $0.05 \%$ glutaraldehyde (final concentrations), and stored frozen at $-70^{\circ} \mathrm{C}$. Cell counts were performed with a FACSCalibur flow cytometer after staining with Syto13 (Gasol \& del Giorgio 2000).

Bacterial production was measured using the $\left[{ }^{3} \mathrm{H}\right]-$ leucine incorporation method (Kirchman et al. 1985), as subsequently modified by Smith \& Azam (1992). For each sample, triplicate aliquots $(1.2 \mathrm{ml})$ and a trichloroacetic acid killed control were incubated with $\left.40 \mathrm{nM} \mathrm{[}{ }^{3} \mathrm{H}\right]$-leucine (final concentration) for 1 to $1.5 \mathrm{~h}$, at in situ temperature in darkness. Previous studies in the studied sea area have shown that leucine incorporation rates are saturated at concentrations of 20 to 40 nM (Gasol et al. 1998, Pedrós-Alió et al. 1999). Thus, even at the highest incorporation rates found in the present study (approximately $11 \mathrm{nmol} \mathrm{leu} \mathrm{l}^{-1} \mathrm{~h}^{-1}$ ), the leucine uptake should have been saturated; even if this were not the case, our measurements should represent a slight underestimation, and therefore a conservative estimate, of leucine incorporation rates in the $\mathrm{P}$ 
enriched bottles. The variability in leucine incorporation rates between replicate bottles using the shortterm nutrient limitation bioassay approach is frequently $<10 \%$.

Collection of microbial community DNA. A 11 aliquot of the long-term bioassays was filtered through a $0.2 \mu \mathrm{m}$ pore-size polycarbonate filter at $<200 \mathrm{~mm} \mathrm{Hg}$ to collect bacterial cells. Filters were immediately frozen at $-70^{\circ} \mathrm{C}$ in sucrose buffer until further processing; community DNA was obtained using a standard phenol-extraction protocol (Schauer et al. 2003).

Denaturing gradient gel electrophoresis (DGGE). DGGE and gel analysis were performed as previously described (Schauer et al. 2003). Briefly, 16S rRNA gene fragments (around $550 \mathrm{bp}$ in length) were amplified by PCR, using the universal primer $907 \mathrm{rm}$ complimentary to positions 927 to 907 (5'-CCGTCAATTCA/ CTTTGAGTTT) and the bacterial specific primer 358 f complementary to positions 341 to 358, with a GC clamp (underlined) (5'-CGCCCGCCGCGCGCGGCGGGCGGGGCGGGGG-CACGGGGGGCCTACG GGAGGCAGCAG). PCR products were loaded on a $6 \%$ polyacrylamide gel with a DNA-denaturant gradient ranging from 40 to $80 \%$. The gel was run at $100 \mathrm{~V}$ for $16 \mathrm{~h}$ at $60^{\circ} \mathrm{C}$ in $1 \times \mathrm{TAE}(40 \mathrm{mM}$ Tris [pH $=7.4$ ], $20 \mathrm{mM}$ sodium acetate, $1 \mathrm{mM}$ EDTA) running buffer. DGGE analysis of samples from the duplicate $\mathrm{N}+\mathrm{P}$ and control cultures from each experiment consistently yielded identical number of bands and band intensities of the duplicates (e.g. see Fig. 4). DGGE bands were excised, reamplified, and verified by a second DGGE. Bands were sequenced using Primer 358f without the GC-clamp, with the BigDye terminator cycle-sequencing kit (Perkin Elmer) and an ABI PRISM Model 377 (v3.3) automated sequencer. Our 16S rRNA gene sequences were compared to sequences in GenBank using BLAST. (For GenBank Accession Nos. of sequences determined in the present study see Table 2).

\section{RESULTS}

\section{Chlorophyll $a$ and nutrients}

The concentrations of chl a were between 1.0 and $2.0 \mu \mathrm{g} \mathrm{l}^{-1}$ from January to March 2003, and thereafter fell to values below $0.5 \mathrm{\mu g} \mathrm{l}^{-1}$ from April to October (Fig. 1A). Following a period of stormy weather at the beginning of October, chl a increased to a peak at $4.0 \mathrm{\mu g} \mathrm{l}^{-1}$ in December, and settled to around $1.2 \mu \mathrm{g} \mathrm{l}^{-1}$ from January to April 2004. Chl a decreased again to low summer values $\left(<0.5 \mu \mathrm{g} \mathrm{l}^{-1}\right)$ from May onwards.

Dissolved inorganic nitrogen (DIN) concentrations from January to April 2003 were between 1.5 and $4.2 \mu \mathrm{M}$, and thereafter fell below $0.9 \mu \mathrm{M}$ until Septem-

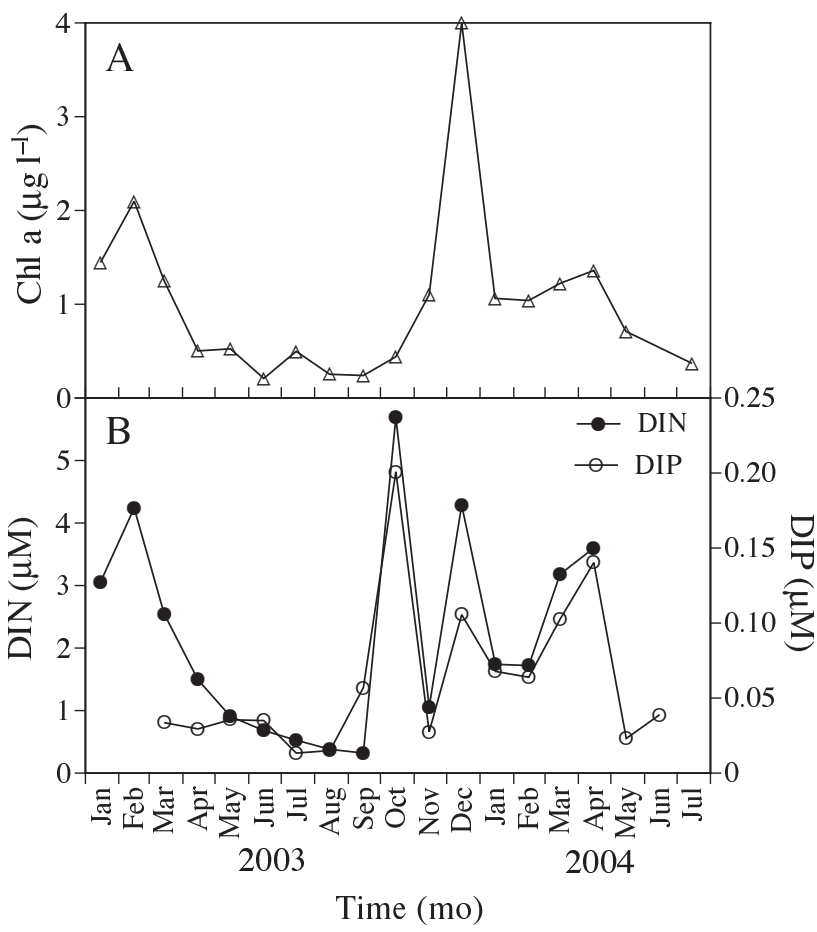

Fig. 1. Seasonal dynamics of (A) chl $a$, and (B) dissolved inorganic nitrogen (DIN) and phosphorus (DIP) concentrations in the NW Mediterranean Sea

ber (Fig. 1B). In October 2003 a pronounced peak at $5.7 \mu \mathrm{M}$ was observed after the storm. Thereafter, concentrations were mostly above $1.7 \mu \mathrm{M}$. Concentrations of dissolved inorganic $\mathrm{PO}_{4}$ (DIP) were mostly below $0.05 \mu \mathrm{M}$ from March to November 2003. However, a peak at $0.22 \mu \mathrm{M} P$ was reached in October (Fig. 1B). Values remained between 0.07 and $0.15 \mu \mathrm{M}$ during winter and spring, and fell below $0.05 \mu \mathrm{M}$ from May 2004 onwards. There was a strong positive correlation between DIN and DIP (DIN = 27.4 DIP + 0.19, p < 0.01, $\mathrm{R}^{2}=0.81$ ), possibly indicating the importance of nutrient input through water mixing with nutrient rich deep water from the coastal shelf moving through the nearby Blanes canyon.

The concentration of total dissolved nitrogen (TDN) varied between 7 and $12 \mu \mathrm{M}$ during the sampling period, while total dissolved phosphorus (TDP) was slightly lower in spring and summer compared to winter (Table 1). The TDN:TDP ratio was between 102 and 207 during spring and summer, and below 100 during late autumn and winter.

During the investigated period the concentrations of DOC ranged from 83 to $177 \mu \mathrm{M}$. During winter 2003 concentrations were around $170 \mu \mathrm{M}$, and decreased to values between 85 to $105 \mu \mathrm{M}$ from May to August (Table 1). A second peak was reached in September 2003 at $117 \mu \mathrm{M}$, after which concentrations declined to a minimum of $83 \mu \mathrm{M}$ in February 2004. 
Table 1. Environmental variables and indicators of bacterial nutrient limitation in Bay of Blanes from 28 January 2003 to 19 July 2004. nd: not determined. TDP: concentrations in boldface represent values $<0.10 \mu \mathrm{M}_{i}$ TDN:TDP: ratios in boldface represent values $>100 ; \mathrm{C}+\mathrm{P}:-,+,++$ indicate stimulation $<20,20-100$ and $>100 \%$, respectively, compared to treatment with $\mathrm{P}$ only; C, P, N + P:,,-+++ indicate stimulation $<20,20-100 \%$ and $>100 \%$, respectively, compared to unamended controls

\begin{tabular}{|c|c|c|c|c|c|c|c|c|c|c|}
\hline \multirow[t]{3}{*}{ Expt } & \multirow[t]{3}{*}{ Date } & \multirow{3}{*}{$\begin{array}{c}\text { Temp } \\
\left({ }^{\circ} \mathrm{C}\right)\end{array}$} & \multirow{3}{*}{$\begin{array}{c}\text { DOC } \\
(\mu \mathrm{M}, \text { mean } \pm \mathrm{SD})\end{array}$} & \multirow{3}{*}{$\begin{array}{l}\text { TDN } \\
(\mu \mathrm{M})\end{array}$} & \multirow{3}{*}{$\begin{array}{l}\text { TDP } \\
(\mu \mathrm{M})\end{array}$} & \multirow[t]{3}{*}{ TDN:TDP } & \multicolumn{4}{|c|}{ Growth response in bioassays } \\
\hline & & & & & & & & prt-te & & Long-term \\
\hline & & & & & & & $\mathrm{C}+\mathrm{P}$ & $\mathrm{C}$ & $\mathrm{P}$ & $\mathrm{N}+\mathrm{P}$ \\
\hline Jan 03 & 28 Jan & 14.0 & nd & nd & nd & nd & - & - & + & - \\
\hline Feb 03 & 4 Mar & 11.0 & $176.9 \pm 4.4$ & nd & nd & nd & + & + & - & - \\
\hline Mar 03 & 25 Mar & 13.0 & $164.6 \pm 2.2$ & 9.42 & 0.07 & 135 & ++ & - & ++ & + \\
\hline Apr 03 & 22 Apr & 14.5 & $112.5 \pm 1.2$ & 9.26 & 0.07 & 132 & ++ & - & ++ & ++ \\
\hline May 03 & 13 May & 17.0 & $92.9 \pm 0.6$ & 7.79 & 0.06 & 130 & ++ & - & ++ & ++ \\
\hline Jun 03 & 25 Jun & 25.0 & $102.5 \pm 10.6$ & 10.33 & 0.05 & 207 & - & - & ++ & ++ \\
\hline Jul 03 & $14 \mathrm{Jul}$ & 25.0 & $85.0 \pm 7.1$ & 8.05 & 0.05 & 161 & ++ & - & ++ & ++ \\
\hline Aug 03 & 4 Aug & 25.2 & $88.1 \pm 3.6$ & 7.41 & 0.04 & 185 & ++ & - & ++ & ++ \\
\hline Sep 03 & $16 \mathrm{Sep}$ & 23.0 & $117.1 \pm 4.1$ & 9.46 & 0.07 & 135 & - & - & ++ & + \\
\hline Oct 03 & 21 Oct & 18.0 & $112.9 \pm 0.6$ & 11.68 & 0.17 & 69 & ++ & ++ & - & - \\
\hline Nov 03 & $25 \mathrm{Nov}$ & 16.0 & $91.7 \pm 1.2$ & 7.14 & 0.08 & 89 & ++ & - & + & ++ \\
\hline Dec 03 & $16 \mathrm{Dec}$ & 14.5 & $102.1 \pm 5.3$ & 12.08 & 0.13 & 93 & - & - & + & - \\
\hline Jan 04 & $26 \mathrm{Jan}$ & 14.0 & $103.5 \pm 6.2$ & 9.50 & 0.12 & 79 & ++ & + & - & - \\
\hline Feb 04 & 23 Feb & 12.9 & $82.8 \pm 4.3$ & 8.61 & 0.10 & 86 & + & + & - & - \\
\hline Mar 04 & 22 Mar & 12.9 & $98.8 \pm 4.1$ & 11.50 & 0.17 & 68 & + & - & ++ & $(++)^{a}$ \\
\hline Apr 04 & 19 Apr & 12.6 & $116.3 \pm 1.8$ & 11.30 & 0.09 & 126 & + & + & - & nd \\
\hline May 04 & 25 May & 17.0 & $122.5 \pm 2.4$ & 10.82 & 0.08 & 135 & + & - & ++ & nd \\
\hline Jun 04 & 28 Jun & 21.1 & $113.3 \pm 0.1$ & 11.21 & 0.11 & 102 & + & - & + & nd \\
\hline Jul 04 & $19 \mathrm{Jul}$ & 24.0 & $126.3 \pm 4.1$ & nd & nd & nd & ++ & - & ++ & nd \\
\hline
\end{tabular}

\section{Short-term nutrient limitation bioassays}

These bioassays were done to determine the bacterioplankton growth response to nutrient enrichment in $24 \mathrm{~h}$ incubations with water filtered through $200 \mu \mathrm{m}$ mesh (i.e. in the presence of flagellate grazing). Leucine incorporation in the controls without nutrient addition remained well below $1 \mathrm{nmol} \mathrm{l^{-1 }} \mathrm{h}^{-1}$ throughout the sampling period (average \pm SD: $0.39 \pm 0.39, \mathrm{n}=$ 19, Fig. 2). Leucine incorporation rates in the treatments that received additions of only $\mathrm{N}$ did not differ significantly from those in the control.

Leucine incorporation rates in the treatment with only C increased 20 to $50 \%$ compared to the control in 4 out of 19 experiments (February 2003, January, February and April 2004), i.e. primarily during winter, Fig. 2 \& Table 1). In a fifth experiment (October 2003), the addition of only $\mathrm{C}$ resulted in a 5 -fold stimulation compared to the control, reaching $6 \mathrm{nmol} \mathrm{l}^{-1} \mathrm{~h}^{-1}$, which was the highest value recorded for any single nutrient addition during the study (Fig. 2).

The addition of only $\mathrm{P}$ stimulated bacterial production on 14 of the 19 sampling occasions (Fig. 2). Very little or no stimulation by $\mathrm{P}$ addition $(<50 \%$ compared to the control) was observed from January to April 2003, and from October 2003 to April 2004. However, from May to September 2003, and from May 2004 onwards, bacterial activity was strongly stimulated by
P addition (i.e. $>100 \%$ increase compared to unamended controls; Table 1). During these summer periods leucine incorporation rates in the $\mathrm{P}$ treatments generally ranged from 1.3 to $2.4 \mathrm{nmol} \mathrm{leu} \mathrm{l}^{-1} \mathrm{~h}^{-1}$, with a pronounced peak at $5.9 \mathrm{nmol} \mathrm{leu} \mathrm{l}^{-1} \mathrm{~h}^{-1}$ in September 2003 (Fig. 2).

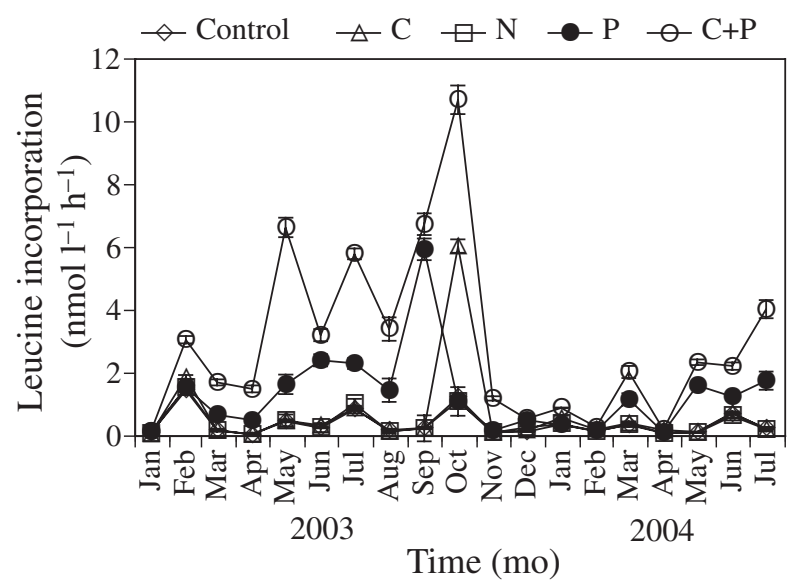

Fig. 2. Nutrient limitation of bacterioplankton during sampling period. Stimulation of bacterial production after addition of glucose $(\mathrm{C})$, ammonium $(\mathrm{N})$ and phosphate $(\mathrm{P})$, and after combined additions of $\mathrm{C}$ and $\mathrm{P}(\mathrm{C}+\mathrm{P})$, compared to control. Leucine incorporation rates were measured $24 \mathrm{~h}$ after addition of nutrients. Error bars represent standard deviations for pooled measurements of triplicate subsamples from each duplicate treatment $(\mathrm{n}=6)$ 
Combined additions of glucose (C) and P caused nearly a doubling or more of leucine incorporation compared to any of the single nutrient additions on 15 of the 19 sampling occasions (exceptions being January, June, September, and December 2003, Fig. 2). Leucine incorporation rates in the combined $\mathrm{C}+\mathrm{P}$

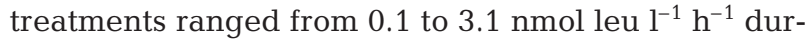
ing winter (November to April), and from 2.2 to

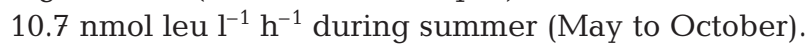
Combined additions of $\mathrm{C}+\mathrm{P}$ in October 2003 caused the largest stimulation of leucine incorporation observed during the study $\left(10.7 \mathrm{nmol} \mathrm{leu} \mathrm{l}^{-1} \mathrm{~h}^{-1}\right)$.

\section{Long-term nutrient limitation bioassays}

The bacterial response to nutrient enrichment in $24 \mathrm{~h}$ experiments could possibly be suppressed during periods of lower temperatures, potentially underestimating nutrient limitation. To reduce this problem, and to avoid potentially confounding impacts of flagellate grazing on bacteria, the growth of bacteria was also monitored in seawater dilution cultures with and without $\mathrm{N}+\mathrm{P}$ enrichment to evaluate the bacterioplankton growth potential over several days (until stationary phase). The yield of bacteria in the seawater cultures varied substantially during the sampling period, ranging from 0.2 to $5.0 \times 10^{6}$ cells ml $^{-1}$ (Fig. 3A), although most yields were within 0.5 to $1.5 \times 10^{6} \mathrm{cells} \mathrm{ml}^{-1}$, which was within the range of bacterial abundances in situ (L. Alonso-Sáez et al. unpubl.). Bacterial abundance in the enriched and control seawater cultures reached similar levels ( $<15 \%$ difference) on 6 sampling occasions, coinciding with the times when no or only slight P limitation was detected in the short-term bioassays (i.e. during winter, Table 1 \& Fig. 3A). On 9 of the sampling occasions bacterial growth was significantly ( 20 to $250 \%$ ) higher in the $\mathrm{N}+\mathrm{P}$ cultures compared to the controls, most notably so during summer when strong P limitation was also found in the shortterm bioassays (i.e. April to September 2003, Table 1). Bacterial growth rates in the unamended controls and the $\mathrm{N}+\mathrm{P}$ enriched cultures ranged from 1.1 to 4.7 and 1.7 to $7.2 \mathrm{~d}^{-1}$, respectively (Fig. 3B). In general, the largest differences between treatments were found at times when differences were also observed in bacterial yields (i.e. May to September and November 2003).

\section{Bacterioplankton composition in the long-term bioassays}

The seawater cultures allowed monitoring of changes in the composition of bacterioplankton assemblages in the enriched seawater cultures as compared
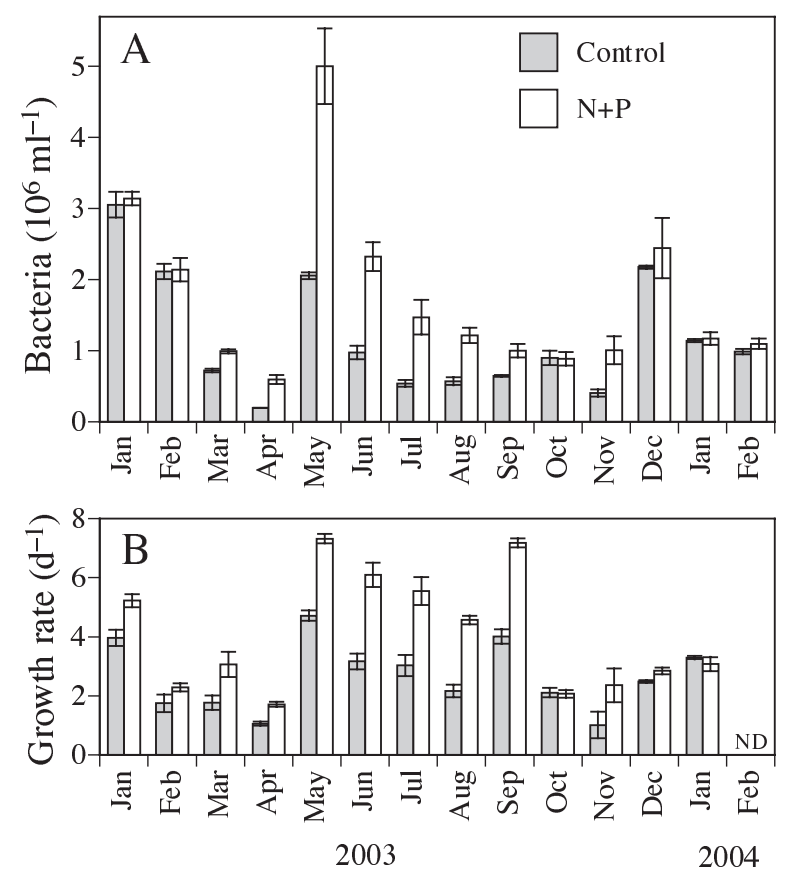

Fig. 3. (A) Bacterial yields and (B) growth rates in seawater cultures enriched with $\mathrm{N}+\mathrm{P}$ compared to unenriched controls. Yields were determined after entry into stationary phase. Error bars denote standard deviations for duplicate seawater cultures. ND: not determined

to the controls; that is, to test whether differences in growth yields were associated with changes in the composition of the bacterial assemblage. Furthermore, identification of specific bacterial phylotypes would indicate whether the observed growth responses were due only to fast-growing bacterial 'weeds' or whether bacteria representative of the native bacterial assemblage were present among those dominating the seawater cultures.

Fig. 4 shows the denaturing gradient gel electrophoresis (DGGE) 'fingerprints' of the bacterial assemblages in the duplicate $\mathrm{N}+\mathrm{P}$ cultures compared to the unamended controls and to the initial sample from July 2003, which was the experiment in which differences in bacterioplankton composition between treatments were most pronounced. From January to May 2003 and from October 2003 to March 2004 (10 experiments) similar pair-wise comparisons resulted in bacterial assemblages in the $\mathrm{N}+\mathrm{P}$ cultures and controls that were identical, or with only slight differences in band intensity of shared bands (data not shown). However, from June to September 2003 a number of phylotypes thrived specifically in the $\mathrm{N}+\mathrm{P}$ cultures, in addition to the phylotypes found in both treatments (Fig. 5). Phylotypes specific to the $\mathrm{N}+\mathrm{P}$ cultures during summer included 3 Bacteroidetes (B218, B221 and B219) and 3 Alphaproteobacteria phylotypes (B243, 


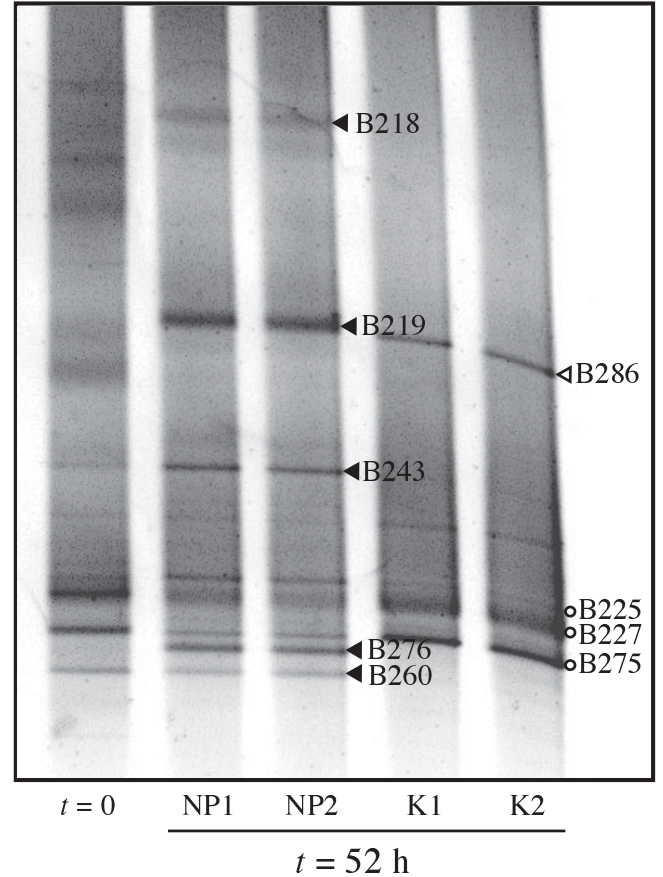

Fig. 4. DGGE fingerprints of bacterial assemblage in duplicate $\mathrm{N}+\mathrm{P}$ cultures (NP1, NP2) compared to unamended controls (K1, K2) and initial sample $(t=0)$ from July 2003, determined by DGGE of PCR-amplified partial 16S rRNA genes. Excized and sequenced bands are indicated by their codes. o: phylotypes present in both enriched and control cultures; black arrowheads: bands present in enriched cultures only; open arrowhead: phylotype found in control culture only. Identities of sequenced bands in Table 2
B276 and B260) (Table 2). In addition, 1 phylotype (B286; Bacteroidetes) was found only in the controls in June and July 2003.

The composition of the bacterioplankton assemblage in the $\mathrm{N}+\mathrm{P}$ enriched seawater cultures changed substantially during the sampling period (Fig. 5). Flavobacteria phylotype B218 (Tenacibaculum sp.) was found in low relative abundance during most of the sampling period, but became the single most abundant phylotype during November and December 2003 both in the control and $\mathrm{N}+\mathrm{P}$ treatments, coinciding with the rapid increase in nutrients and chl a following the storm in October (Fig. 1). In summer 2003, phylotype B218 was restricted to the $\mathrm{N}+\mathrm{P}$ cultures where it occurred together with Bacteroidetes phylotype B219 (Microscilla cluster, cf. Kirchman et al. 2003). Another Bacteroidetes phylotype, B286 (novel Bacteroidetes lineage), became abundant in the control cultures in June and July 2003. Flavobacteria phylotype B240 (Polaribacter sp.) was the most abundant phylotype in the cultures from March to May 2003 and was also abundant from January to March 2004, but was not detected between the spring periods (i.e. from June to December 2003).

The Roseobacter phylotype B243 was found in the seawater cultures only during spring and early summer; it occured in both the $\mathrm{N}+\mathrm{P}$ cultures and controls from March to May, but thereafter was found only in the N+P cultures in June and July 2003. A total of 4 identified Roseobacter phylotypes occurred mainly

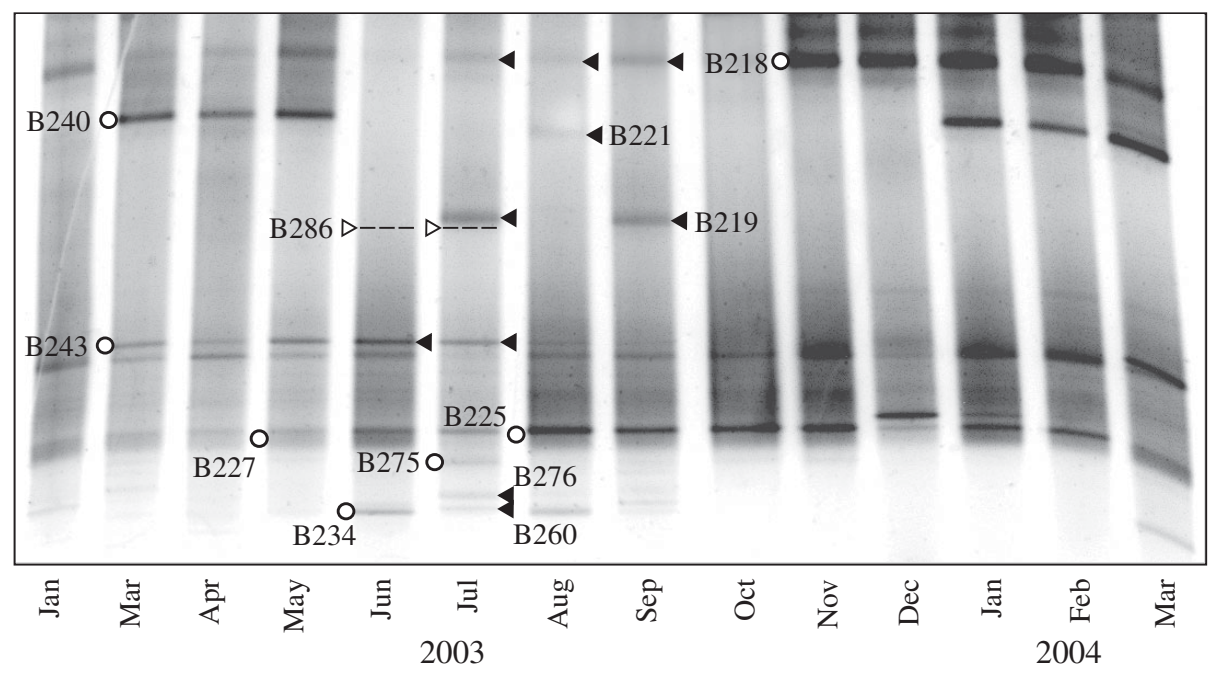

Time (yr, mo)

Fig. 5. DGGE fingerprints of bacterial assemblages in $\mathrm{N}+\mathrm{P}$ enriched seawater culture experiments visualized by DGGE of PCR-amplified partial 16S rRNA genes. Samples for community DNA were collected after 2 to $4 \mathrm{~d}$ incubation. O and unlabelled bands (since the latter were not sequenced): phylotypes present in both enriched and control cultures; black arrowheads: bands present in enriched cultures only. Open arrowheads: position of phylotype B286, which was found in control cultures only (e.g. see Fig. 4) and not in samples shown here. The stippled bands of this phylotype have been drawn on top of the image. 
Table 2. Phylogenetic affiliation of 16S rRNA gene sequences from excised DGGE bands obtained during long-term bioassays. For each phylotype, closest relative in GenBank and closest cultured relative are shown, together with their accession numbers and sequence similarity. Uncult.: uncultured; CFB: Cytophaga-Flavobacterium-Bacteroides or Bacteroidetes phylum; Alpha: Alphaproteobacteria; Gamma: Gammaproteobacteria

\begin{tabular}{|c|c|c|c|c|c|}
\hline $\begin{array}{l}\text { Phylo- } \\
\text { type }\end{array}$ & $\begin{array}{l}\text { Accession } \\
\text { number }\end{array}$ & Relatives in GenBank; Accession no. & $\begin{array}{c}\text { Similarity } \\
(\%)\end{array}$ & Family & Taxon \\
\hline \multirow[t]{2}{*}{ B218 } & DQ473559 & Uncult. marine bacterium BY-65, AJ298376 & 100.0 & & \\
\hline & & Tenacibaculum mesophilum, AB032504 & 98.1 & Flavobacteriaceae & CFB \\
\hline \multirow[t]{2}{*}{ B219 } & DQ473560 & Uncult. Bacteroidetes Clone CF96, AY274863 & 97.0 & & \\
\hline & & Owenweeksia hongkongensis, AB125062 & 91.2 & Cryomorphaceae & CFB \\
\hline \multirow[t]{2}{*}{ B221 } & DQ473561 & Uncult. Bacteroidetes DGGE Band S-1, AY573520 & 100.0 & & \\
\hline & & Cellulophaga fucicola, AJ005973 & 92.4 & Flavobacteriaceae & CFB \\
\hline \multirow[t]{2}{*}{$\mathrm{B} 225^{\mathrm{a}}$} & & Uncult. Alphaproteobacterium, Clone PI_4a9f, AY580451 & $>97$ & & \\
\hline & & Roseovarius mucosus, AJ534215 & $>96$ & Rhodobacteraceae & Alpha \\
\hline \multirow[t]{2}{*}{ B227 } & DQ473562 & Uncult. Glaciecola sp. Clone F2C105, AY794109 & 99.0 & & \\
\hline & & Alteromonas addita, AY682202 & 96.5 & Alteromonadaceae & Gamma \\
\hline \multirow[t]{2}{*}{ B234 } & DQ473563 & Uncult. bacterium Clone ELB19-099, DQ015817 & 97.9 & & \\
\hline & & Loktanella koreensis Strain GA2-M3, DQ344498 & 97.5 & Rhodobacteraceae & Alpha \\
\hline \multirow[t]{2}{*}{ B240 } & DQ473564 & Uncult. Bacteroidetes Clone CF10, AY274847 & 100 & & \\
\hline & & Polaribacter dokdonensis Strain DSW-5, DQ004686 & 97.2 & Flavobacteriaceae & CFB \\
\hline \multirow[t]{2}{*}{ B243 } & DQ473565 & Alphaproteobacterium 9IX/A01/152, AY612764 & 100.0 & & \\
\hline & & Nereida ignava, AJ748748 & 99.6 & Rhodobacteraceae & Alpha \\
\hline \multirow[t]{2}{*}{ B260 } & DQ473566 & Uncult. Roseobacter DGGE Band ST-13, AY573530 & 100.0 & & \\
\hline & & Phaeobacter inhibens, AY177712 & 97.7 & Rhodobacteraceae & Alpha \\
\hline \multirow[t]{2}{*}{ B275 } & DQ473567 & Uncult. Rhodobacteraceae Clone DS023, DQ234107 & 100.0 & & \\
\hline & & Roseobacter algocolus, X78315 & 97.5 & Rhodobacteraceae & Alpha \\
\hline \multirow[t]{2}{*}{$\mathrm{B} 276^{\mathrm{a}}$} & & Uncult. Roseobacter DGGE Band ST-13, AY573530 & $>96$ & & \\
\hline & & R. algocolus (ATCC 51440 T-FF3), X78315 & $>95$ & Rhodobacteraceae & Alpha \\
\hline \multirow[t]{2}{*}{ B286 } & DQ473568 & Uncult. marine bacterium BY-71, AJ298380 & 91.7 & & \\
\hline & & Owenweeksia hongkongensis, AB125062 & 89.9 & Cryomorphaceae & CFB \\
\hline
\end{tabular}

from June to September, of which 2 (phylotypes B260 and B276) were restricted to the $\mathrm{N}+\mathrm{P}$ cultures. Roseobacter phylotype B225 and Alteromonas phylotype B227 were detected in both treatments throughout the sampling period. Phylotype B225 achieved a particularly high relative abundance in the seawater cultures from August to November 2003.

\section{DISCUSSION}

Chl a concentrations in Blanes Bay followed the seasonal dynamics regularly observed in the coastal NW Mediterranean Sea, with low values during summer and maximum values in winter (Duarte et al. 1998, Schauer et al. 2003). Phytoplankton growth in the Mediterranean Sea is primarily P limited (Berland et al. 1980, Krom et al. 1991); thus, the low concentrations of chl a during summer are consistent with the low concentrations of DIP observed during this period. The elevated concentrations of chl a during late autumn and winter are consistent with increased availability of $\mathrm{P}$ and other mineral nutrients at these times. As a consequence of the seasonal changes in growth conditions there is a typical seasonal succession of phytoplankton in the NW Mediterranean Sea, from a winter bloom dominated by diatoms, followed by Synechococcus spp. in summer and a minor autumn bloom of Prochlorococcus spp. (Schauer et al. 2003). Considering the strong effect of nutrients on phytoplankton growth and community composition in the NW Mediterranean Sea and elsewhere (Agawin et al. 2000, Duarte et al. 2000, Olsen 2006), we investigated the extent to which bacterioplankton was subjected to similar forcing by nutrient availability.

Both short- and long-term nutrient enrichment experiments showed that bacterial growth was strongly limited by the availability of $\mathrm{P}$ during the period following the winter phytoplankton bloom until the breakdown of water column stratification in autumn (Table 1). Although P limitation could occur all through the year, its severity was most pronounced during spring and summer, coinciding with (for example) very low concentrations of DIP and chl $a$ and higher N:P ratios. These findings are in agreement with previous data showing that bacterial growth in the Mediterranean Sea is strongly P limited in summer (Zweifel et al. 1993, Thingstad et al. 1998, Sala et al. 2002, Tanaka et al. 2004). However, Thingstad et al. (1998) suspected that P limitation would primarily be 
restricted to the summer period, while during other seasons mixing of surface and deep water would alleviate $\mathrm{P}$ limitation and possibly lead to $\mathrm{C}$ limitation. Similarly, Zohary \& Robarts (1998) suggested that $\mathrm{P}$ limitation in the eastern Mediterranean Sea may be less pronounced during periods when water column stratification is weakened. Indeed, subsequent studies indicated that the microbial turnover of $\mathrm{P}$ in the NW Mediterranean is significantly slower during nonsummer seasons, suggesting that $\mathrm{P}$ limitation may be less pronounced at these times (Tanaka et al. 2003, 2004). No incidence of inorganic $N$ limitation was detected during our study, and observations of inorganic $\mathrm{N}$ limitation of bacterial growth in marine surface waters seem to be relatively uncommon (but see Sala et al. 2002). In the present study, C limitation of bacterial growth was observed on several occasions from October to April, thus providing experimental evidence for the hypothesis of Thingstad et al. (1998). It is thus concluded that bacteria in the NW Mediterranean are strongly $\mathrm{P}$ limited during stratification periods (i.e. summer), while during periods of mixing, bacteria experience shifts in the primary limiting nutrient ( $\mathrm{P}$ versus $\mathrm{C}$ ) and in the severity of limitation. Considering that, for example, DOC sequestration is significantly enhanced when bacteria are C limited (Carlson et al. 2002) while accumulation of labile DOC may take place when bacterial growth is limited by inorganic nutrients (Zweifel et al. 1995), our findings suggest that frequent shifts in the type of nutrient limitation could have large consequences for biogeochemical processes driven by bacterioplankton.

On two occasions the single addition of nutrients evoked particularly large responses in leucine incorporation in the short-term bioassays. These occurred in September and October 2003, when very strong responses to enrichment with $\mathrm{P}$ and $\mathrm{C}$ were observed, respectively. In both experiments, the stimulation of leucine incorporation was as large (approximately $6 \mathrm{nmol} \mathrm{leu} \mathrm{l}^{-1} \mathrm{~h}^{-1}$ ) as that induced by combined additions of $\mathrm{C}+\mathrm{P}$ during the summer months (when $\mathrm{P}$ was the primary limiting nutrient). Incidentally, DOC concentrations in the Bay of Blanes had increased by nearly $30 \mu \mathrm{M}$ in September compared to the previous months (Table 1). Thus, it is possible that the strong response (as strong as the response in the combined $\mathrm{C}+\mathrm{P}$ treatment), was due to a recent buildup of the labile organic carbon pool (i.e. the $\mathrm{P}$ enriched treatment essentially became a natural $\mathrm{C}+\mathrm{P}$ treatment). Conversely, the large stimulation of bacterial leucine incorporation by the addition of $\mathrm{C}$ in October coincided with an in situ peak in inorganic $\mathrm{PO}_{4}$ concentration of $0.22 \mu \mathrm{M}$. This peak followed a period of stormy weather, which could have caused increased P availability through mixing with nutrient rich deep water from off the coast. These 2 'extreme' situations, separated by only $1 \mathrm{mo}$, are evidence of how rapidly and with what magnitude bacterioplankton nutrient limitation can potentially change in any specific marine area. We suspect that given a higher frequency of sampling, such changes could even be detected within days to weeks.

Knowledge of microbial nutrient limitation in different ocean provinces derives from experiments ranging from the kilometer scale of in situ enrichments (Martin et al. 1994, Boyd et al. 2000, Krom et al. 2005) down to the centimeter scale in bottle incubations (Kirchman 1990, Zweifel et al. 1993). Irrespective of the experimental scale, detection of limitation primarily relies on observation of changes in microbial production and abundance (of phyto- or bacterioplankton, or both). It is reasonable to assume that experimental scale as well as bioassay approach (e.g. the use of filtered or unfiltered samples) will affect the details of how microbes respond. Nevertheless, the general conclusions derived from different experimental approaches are likely to be similar. For heterotrophic bacteria, shortterm bioassays (typically $24 \mathrm{~h}$ ) with unfiltered water provide straightforward indications of nutrient limitation (Thingstad et al. 1998), but relatively limited additional information. Long-term bioassays, such as seawater dilution cultures, on the other hand, provide not only direct estimates of limitation and substrate utilization, but also indications of growth kinetics and diversity of bacteria responding to the enrichment. In particular, this approach has been rewarding in yielding information on the preferences for growth of diverse representatives of Alpha- and Gammaproteobacteria and Bacteroidetes (Eilers et al. 2000, Covert \& Moran 2001, Kisand \& Wikner 2003, Pinhassi \& Berman 2003).

Two findings concerning the changes in composition of the bacterioplankton assemblages in our seawater cultures were most conspicuous. First, the composition in the control and enriched cultures were similar at those times when little or no P limitation was detected (i.e. during non-summer seasons). However, when bacterioplankton growth was strongly $\mathrm{P}$ limited (i.e. June to September), large differences between the enriched and the unenriched treatments were found (with the exception of the experiments in May and November 2003). In the experiments during summer, 6 phylotypes reached a high relative abundance exclusively in the $\mathrm{N}+\mathrm{P}$ enriched seawater cultures. Since there were no indications that $\mathrm{N}$ ever limited the growth of bacteria in the Bay of Blanes, the growth response of these bacteria was attributed to the increased availability of P. The responses of Roseobacter B243 and Tenacibaculum B218 were particularly interesting. Roseobacter B243 was abundant both in the enriched cultures and the controls, from March to 
May. In June and July, however, when P limitation was most pronounced, this phylotype was encountered only in the enriched cultures. Similarly, Tenacibaculum B218 was found in both enriched and control cultures during non-summer seasons, but in July and September in the enriched cultures only. Both these phylotypes have been previously detected in situ, in spring, before the onset of summer stratification, by culture-independent techniques (see below). The differences in composition of the bacterial assemblages in the seawater cultures during summer (i.e. during times of strong P limitation) imply that during this period the availability of $\mathrm{P}$ has the potential to directly affect bacterioplankton composition.

Second, the composition in both the control and enriched cultures changed substantially during the sampling period, with pronounced changes between seasons. Seasonal changes in bacterioplankton composition are a common feature in temperate seas (Pinhassi \& Hagström 2000, Schauer et al. 2003, Ghiglione et al. 2005, Morris et al. 2005). At the same study site as in the present study, Schauer et al. (2003) showed that bacterioplankton composition was relatively stable with respect to the broad phylogenetic groups present (e.g. Alphaproteobacteria and Bacteroidetes), but that changes occurred in the abundance of specific phylotypes within these groups over a 1 yr period. Specifically, shifts in bacterioplankton composition were observed from winter to spring and from spring to summer (Schauer et al. 2003). Several sequences from the seawater culture DGGE analyses were identical to DGGE phylotypes or $16 \mathrm{~S}$ rRNA gene clone library sequences obtained from in situ samples from the Bay of Blanes, suggesting that their occurrence in the cultures was related to their occurrence in situ. For example, Tenacibaculum phylotype B218 (Flavobacteriaceae), which was dominant in the seawater cultures during the phytoplankton bloom period November 2003 to March 2004, was identical to in situ DGGE phylotype BL98-5. BL98-5 was one of the dominant phylotypes during the phytoplankton bloom in the Bay of Blanes from February to April 1998 (Schauer et al. 2003). Roseobacter phylotype B243, which was found to be an important member of the N + P seawater cultures from March to July 2003, was identical to 16S rRNA gene Clone SPR23 found in a clone library from May 2003 (L. Alonso-Sáez et al. unpubl.). Roseobacter phylotype B275, which was found in the seawater cultures only during summer, was identical to phylotype BL98-35. BL98-35 was an important member of the bacterioplankton assemblage in Bay of Blanes in summer 1998 (Schauer et al. 2003), and it was nearly identical to 16S rRNA gene Clone SUM30 found in August 2003 (L. Alonso-Sáez et al. unpubl.). Furthermore, some bands observed to develop in the seawater cultures corresponded to bands present also in the in situ samples (e.g. bands B243, B275 and B260 in July 2003, Fig. 4). Members of the SAR11 clade are an integral component of Mediterranean Sea microbial communities (Zaballos et al. 2006), yet were not detected in our seawater dilution cultures. This was probably due to the slow growth rates of SAR11 bacteria (approximately 0.4 to $0.6 \mathrm{~d}^{-1}$; Rappé et al. 2002) compared to the bacteria that thrived in the cultures (approximately 1.0 to $7.0 \mathrm{~d}^{-1}$ ). Langenheder et al. (2006) recently investigated the composition of bacterial assemblages that developed in lakewater cultures with inocula from different lakes. They concluded that the original composition of the inoculum was a central factor in determining the final structure of the bacterial assemblages in their experiments. This would lend support to the suggestion that the seasonal changes observed in our experiments occurred largely in response to in situ changes in bacterioplankton composition in combination with changes in the nutrient regime.

The concentration of organic and inorganic nutrients in most seas typically changes during the year. Our present data suggest that seasonal variability in nutrient availability has strong direct effects on the activity and composition of marine bacterial assemblages. Furthermore, the availability of nutrients directly affects phytoplankton growth and composition. Recent findings indicate that qualitative and quantitative differences in phytoplankton community composition are important for structuring the composition of the bacterial assemblage (Pinhassi et al. 2004, Abell \& Bowman 2005), possibly due to differences in the stoichiometry of organic matter produced by different algae. Thus, changing nutrient concentrations are likely to have both direct and indirect effects on bacterioplankton growth and composition.

Acknowledgements. V. Balagué is thankfully acknowledged for the organization and coordination of the in situ samplings. We thank Erik Lundberg for the help with DOC analyses. We are grateful for the helpful comments and constructive criticism on the manuscript by Lasse Riemann and 3 anonymous reviewers. This work was supported by the Swedish Science Council (project 621-2003-2692, to J.P.), and the Spanish MCyT projects MicroDiff (REN2001-2120/MAR) and MODIVUS (CTM2005-04795/MAR), and the EU project BASICS (EVK3-CT-2002-00078) to J.M.G.

\section{LITERATURE CITED}

Abell GCJ, Bowman JP (2005) Colonization and community dynamics of class Flavobacteria on diatom detritus in experimental mesocosms based on Southern Ocean seawater. FEMS Microbiol Ecol 53:379-391

Agawin NSR, Duarte CM, Agustí S (2000) Nutrient and temperature control of the contribution of picoplankton to phytoplankton biomass and production. Limnol Oceanogr 45:591-600 
Berland BR, Bonin DJ, Maestrini SY (1980) Azote ou phosphore? Considérations sur le 'paradoxe nutritionnel' de la mer mediterranée. Oceanol Acta 3:135-142

Boyd PW, Watson AJ, Law CS, Abraham ER and 31 others (2000) A mesoscale phytoplankton bloom in the polar Southern Ocean stimulated by iron fertilization. Nature 407:695-702

Carlson CA, Ducklow HW, Michaels AF (1994) Annual flux of dissolved organic carbon from the euphotic zone in the Northwestern Sargasso Sea. Nature 371:405-408

Carlson CA, Giovannoni SJ, Hansell DA, Goldberg SJ, Parsons R, Otero MP, Vergin K, Wheeler BR (2002) Effect of nutrient amendments on bacterioplankton production, community structure, and DOC utilization in the northwestern Sargasso Sea. Aquat Microb Ecol 30:19-36

Carlson CA, Giovannoni SJ, Hansell DA, Goldberg SJ, Parsons R, Vergin K (2004) Interactions among dissolved organic carbon, microbial processes, and community structure in the mesopelagic zone of the northwestern Sargasso Sea. Limnol Oceanogr 49:1073-1083

Carlsson P, Caron DA (2001) Seasonal variation of phosphorus limitation of bacterial growth in a small lake. Limnol Oceanogr 46:108-120

Cotner JB, Ammerman JW, Peele ER, Bentzen E (1997) Phosphorus-limited bacterioplankton growth in the Sargasso Sea. Aquat Microb Ecol 13:141-149

Covert JS, Moran MA (2001) Molecular characterization of estuarine bacterial communities that use high- and lowmolecular weight fractions of dissolved organic carbon. Aquat Microb Ecol 25:127-139

Duarte CM, Agustí S, Satta MP, Vaqué D (1998) Partitioning particulate light absorption: a budget for a Mediterranean bay. Limnol Oceanogr 43:236-244

Duarte CM, Agustí S, Agawin NSR (2000) Response of a Mediterranean phytoplankton community to increased nutrient inputs: a mesocosm experiment. Mar Ecol Prog Ser 195:61-70

Eilers H, Pernthaler J, Amann R (2000) Succession of pelagic marine bacteria during enrichment: a close look at cultivation-induced shifts. Appl Environ Microbiol 66:4634-4640

Gasol JM, del Giorgio PA (2000) Using flow cytometry for counting natural planktonic bacteria and understanding the structure of planktonic bacterial communities. Sci Mar 64:197-224

Gasol JM, Doval MD, Pinhassi J, Calderón-Paz JI, GuixaBoixareu N, Vaqué D, Pedrós-Alió C (1998) Diel variations in bacterial heterotrophic activity and growth in the northwestern Mediterranean Sea. Mar Ecol Prog Ser 164:107-124

Ghiglione JF, Larcher M, Lebaron P (2005) Spatial and temporal scales of variation in bacterioplankton community structure in the NW Mediterranean Sea. Aquat Microb Ecol 40:229-240

Grasshoff K, Ehrhardt M, Kremling K (1983) Methods of seawater analysis. Verlag Chemie, Weinheim

Grossart HP, Levold F, Allgaier M, Simon M, Brinkhoff T (2005) Marine diatom species harbour distinct bacterial communities. Environ Microbiol 7:860-873

Hagström Å, Pinhassi J, Zweifel UL (2001) Marine bacterioplankton show bursts of rapid growth induced by substrate shifts. Aquat Microb Ecol 24:109-115

Hutchins DA, Campbell BJ, Cottrell MT, Takeda S, Cary SC (2001) Response of marine bacterial community composition to iron additions in three iron-limited regimes. Limnol Oceanogr 46:1535-1545

Kirchman DL (1990) Limitation of bacterial growth by dissolved organic matter in the subarctic Pacific. Mar Ecol Prog Ser 62:47-54
Kirchman DL, Knees E, Hodson R (1985) Leucine incorporation and its potential as a measure of protein synthesis by bacteria in natural aquatic systems. Appl Environ Microbiol 49:599-607

Kirchman DL, Yu L, Cottrell MT (2003) Diversity and abundance of uncultured Cytophaga-like bacteria in the Delaware Estuary. Appl Environ Microbiol 69:6587-6596

Kisand V, Wikner J (2003) Combining culture-dependent and -independent methodologies for estimation of richness of estuarine bacterioplankton consuming riverine dissolved organic matter. Appl Environ Microbiol 69: 3607-3616

Krom MD, Kress N, Brenner S (1991) Phosphorus limitation of primary productivity in the eastern Mediterranean Sea. Limnol Oceanogr 36:424-432

Krom MD, Thingstad TF, Carbo P, Drakopoulos P and 23 others (2005) Overview of the CYCLOPS P addition Lagrangian experiment in the Eastern Mediterranean. Deep-Sea Res II 52:2879-2896

Langenheder S, Lindström ES, Tranvik LJ (2006) Structure and function of bacterial communities emerging from different sources under identical conditions. Appl Environ Microbiol 72:212-220

Martin JH, Coale KH, Johnson KS, Fitzwater SE and 40 others (1994) Testing the iron hypothesis in ecosystems of the equatorial Pacific Ocean. Nature 371:123-129

Morris DP, Lewis WM Jr (1992) Nutrient limitation of bacterioplankton growth in Lake Dillon, Colorado. Limnol Oceanogr 37:1179-1192

Morris RM, Vergin KL, Cho JC, Rappé MS, Carlson CA, Giovannoni SJ (2005) Temporal and spatial response of bacterioplankton lineages to annual convective overturn at the Bermuda Atlantic Time-Series Study site. Limnol Oceanogr 50:1687-1696

Murray JW, Barber RT, Roman MR, Bacon MP, Feely RA (1994) Physical and biological control on carbon cycling in the equatorial Pacific. Science 266:58-65

Olsen Y (2006) A comparative study of responses in planktonic food web structure and function in contrasting European coastal waters exposed to experimental nutrient addition. Limnol Oceanogr 51:488-503

Pakulski JD, Coffin RB, Kelley CA, Holder SL, Downer R, Aas P, Lyons MM, Jeffrey WH (1996) Iron stimulation of Antarctic bacteria. Nature 383:133-134

Pedrós-Alió C, Calderón-Paz JI, Guixa-Boixereu N, Estrada M, Gasol JM (1999) Bacterioplankton and phytoplankton biomass and production during summer stratification in the northwestern Mediterranean Sea. Deep-Sea Res I 46: 985-1019

Pinhassi J, Berman T (2003) Differential growth response of colony-forming $\alpha$ - and $\gamma$-Proteobacteria in dilution culture and nutrient addition experiments from Lake Kinneret (Israel), the eastern Mediterranean Sea, and the Gulf of Eilat. Appl Environ Microbiol 69:199-211

Pinhassi J, Hagström A (2000) Seasonal succession in marine bacterioplankton. Aquat Microb Ecol 21:245-256

Pinhassi J, Sala MM, Havskum H, Peters F, Guadayol Ò, Malits A, Marrasé C (2004) Changes in bacterioplankton composition under different phytoplankton regimens. Appl Environ Microbiol 70:6753-6766

Pitta P, Stambler N, Tanaka T, Zohary T, Tselepides A, Rassoulzadegan F (2005) Biological response to P addition in the Eastern Mediterranean Sea. The microbial race against time. Deep-Sea Res II 52:2961-2974

Rappé MS, Connon SA, Vergin KL, Giovannoni SJ (2002) Cultivation of the ubiquitous SAR11 marine bacterioplankton clade. Nature 418:630-633 
Rivkin RB, Anderson MR (1997) Inorganic nutrient limitation of oceanic bacterioplankton. Limnol Oceanogr 42:730-740

Sala MM, Peters F, Gasol JM, Pedrós-Alió C, Marrasé C, Vaqué D (2002) Seasonal and spatial variations in the nutrient limitation of bacterioplankton growth in the northwestern Mediterranean. Aquat Microb Ecol 27: 47-56

Schauer M, Balagué V, Pedrós-Alió C, Massana R (2003) Seasonal changes in the taxonomic composition of bacterioplankton in a coastal oligotrophic system. Aquat Microb Ecol 31:163-174

Smayda TJ, Reynolds CS (2001) Community assembly in marine phytoplankton: application of recent models to harmful dinoflagellate blooms. J Plankton Res 23: $447-461$

Smayda TJ, Reynolds CS (2003) Strategies of marine dinoflagellate survival and some rules of assembly. J Sea Res 49: 95-106

Smith DC, Azam F (1992) A simple, economical method for measuring bacterial protein synthesis rates in seawater using 3H-leucine. Mar Microb Food Webs 6:107-114

Tanaka T, Rassoulzadegan F, Thingstad TF (2003) Measurements of phosphate affinity constants and phosphorus release rates from the microbial food web in Villefranche Bay, northwestern Mediterranean. Limnol Oceanogr 48: $1150-1160$

Tanaka T, Rassoulzadegan F, Thingstad TF (2004) Orthophosphate uptake by heterotrophic bacteria, cyanobacteria, and autotrophic nanoflagellates in Villefranche Bay, northwestern Mediterranean: vertical, seasonal, and

Editorial responsibility: Frede Thingstad,

Bergen, Norway short-term variations of the competitive relationship for phosphorus. Limnol Oceanogr 49:1063-1072

Thingstad TF, Hagström A, Rassoulzadegan F (1997) Accumulation of degradable DOC in surface waters: Is it caused by a malfunctioning microbial loop? Limnol Oceanogr 42:398-404

Thingstad TF, Zweifel UL, Rassoulzadegan F (1998) P limitation of heterotrophic bacteria and phytoplankton in the northwest Mediterranean. Limnol Oceanogr 43:88-94

Thingstad TF, Pérez M, Pelegri S, Dolan J, Rassoulzadegan F (1999) Trophic control of bacterial growth in microcosms containing a natural community from northwest Mediterranean surface waters. Aquat Microb Ecol 18:145-156

Thingstad TF, Krom MD, Mantoura RFC, Flaten GAF and 15 others (2005) Nature of phosphorus limitation in the ultraoligotrophic Eastern Mediterranean. Science 309: 1068-1071

Zaballos M, López-López A, Ovreas L, Bartual SG and 6 others (2006) Comparison of prokaryotic diversity at offshore oceanic locations reveals a different microbiota in the Mediterranean Sea. FEMS Microbiol Ecol 56:389-405

Zohary T, Robarts RD (1998) Experimental study of microbial $\mathrm{P}$ limitation in the eastern Mediterranean. Limnol Oceanogr 43:387-395

Zweifel UL, Norrman B, Hagström $\AA$ (1993) Consumption of dissolved organic carbon by marine bacteria and demand for inorganic nutrients. Mar Ecol Prog Ser 101:23-32

Zweifel UL, Wikner J, Hagström Å, Lundberg E, Norrman B (1995) Dynamics of dissolved organic carbon in a coastal ecosystem. Limnol Oceanogr 40:299-305

Submitted: April 9, 2006; Accepted: July 19, 2006

Proofs received from author(s): October 5, 2006 